\title{
The Primary Health Center Factors Associated with Contraceptive Use Among Women in Indonesia
}

\author{
Arini Hardianti ${ }^{1}$, Siswanto Agus Wilopo², Mohammad Hakimi², Althaf Setiawan² \\ ${ }^{1}$ Universitas Alma Ata ,Jalan Brawijaya No 99 Yogyakarta \\ ${ }^{2}$ Biostatistics, Epidemiology and Population Health, Universitas Gadjah Mada, Bulaksumur, \\ Caturtunggal, Depok, Sleman, Yogyakarta \\ Email : hardiantiarini@gmail.com
}

\begin{abstract}
Abstrak
Akses ke pelayanan kesehatan, utamanya adalah waktu layanan kesehatan merupakan salah satu hal penting untuk meningkatkan penggunaan kontrasepsi di Indonesia. Seseorang cenderung ingin mendapatkan metode yang diinginkan pada hari yang sama ketika mengunjungi fasilitas kesehatan. Tujuan dari penelitian ini adalah mengetahui pengaruh jumlah hari layanan KB di fasilitas kesehatan terhadap penggunaan kontrasepsi. Studi cross sectional menggunakan data Performance Monitoring and Accountability (PMA) 2020 di 33 propinsi Indonesia tahun 2015. Subjek penelitian dalah fasilitas kesehatan tingkat pertama (Puskesmas). Pada penelitian ini dilakukan penggabungan beberapa Kabupaten untuk mencapai jumlah responden minimal 30 orang WUS. Diperoleh 104 gabungan kabupaten. Analisa data menggunakan uji statistik ttest dan korelasi dengan melihat tingkat kemaknaan $p<0,05$, dan analisa multivariabel. Hipotesis penelitian ini adalah Proporsi WUS pengguna kontrasepsi modern yang tinggal di wilayah dengan frekuensi hari layanan KB lebih sering cenderung lebih tinggi dibandingkan WUS yang tinggal di wilayah dengan frekeunsi hari layanan KB lebih jarang. Lebih dari tiga per empat wilayah penelitian seluruh puskesmasnya memberikan layanan KB lebih dari 5 hari dan tidak terjadi stock out. Seluruh puskesmas di $69 \%$ wilayah telah memberikan lebih dari 5 metide kontrasepsi. Frekuensi hari layanan KB secara statistik berhubungan dengan penggunaan kontrasepsi pada WUS setelah mempertimbangkan variabel stock out dan metode yang disediakan. Frekuensi hari layanan KB di fasilitas kesehatan sudah baik dan secara berhubungan dengan penggunaan kontrasepsi pada WUS setelah mempertimbangkan variabel stock out dan metode yang disediakan.
\end{abstract}

Kata Kunci: keluarga berencana; puskesmas; Indonesia

\begin{abstract}
Access to health care, especially health care's days open was one of the important poin to increasing contraceptive user. Many people who want to use contraception tend to want to get the method in the same day when visited the health care. The aim of this study is to find the relationship health care days open and contraceptive utilization. The cross-sectional study used Performance Monitoring and Accountability (PMA) 2020 data in 33 provinces of Indonesia in 2015. The research subjects were primary health care (Puskesmas). In this research, a number of districts were merged to reach a minimum number of respondents of 30 women. One hundred and four health center were studied and analyzed with t-test and correlation, and multivariable analysis by looking at the level of significance $p<0.05$, and multivariable analysis. Female, household, and service delivery point questionnaire were used in this study. Result: All health centers in $76 \%$ area in Indonesia open more than five days a week and no stock out more than five contraceptive methods. All health centers in $69 \%$ area provides more than 5 methods. Days open statistically significant
\end{abstract}


with modern contraceptive utilization after considering the stock out and method provides. Conclusion: contraceptive days open in health care generally good and have relation with contraceptive utilization after considers the stock and how many methods they provide.

Keywords: family planning; health center; Indonesia

Article info:

Article submitted on November 02, 2020

Articles revised on November 29, 2020

Articles received on December 15, 2020

DOI: http://dx.doi.org/10.21927/jnki.2020.8(4).261-269

\section{INTRODUCTION}

The international conference on population and development (ICPD) committed to universal access coverage on reproductive health. More than last 20 years many countries have reached big progress in increase access to reproductive health care, efforts to decrease fertility rate, decrease mortality rate, and increase people's education and economic.

Family planning or Keluarga berencana (KB) is means of controlling birth rates, but also serves to preventing maternal and infant morbidity, and empower woman to raise their economics status and provide choice. That appropriate method what women want it, one of the efforts to increase healthy and prosperity of woman, then also to decrease poverty (1-4). The indicator that we can use to evaluate successfully from a program is how the goal that we got it in society (5).

Indonesia is a large country with a population of 237.6 million people which increases every year (6). Indonesia's total fertility rate (TFR) in the year 2003 to 2012 does not decrease the value of 2.6, but from report result Performance Monitoring and Accountability 2020 (PMA 2020) TFR has a value of 2.3. To achieve a balance of growth and development of the population, TFR should achieve grades of 2.1 or 2.2. One way to achieve this goal is to improve the performance of contraceptive use. An indicator to see the achievement of contraceptive use is by a look at the Contraceptive Prevalence Rate (CPR) (7).
IDHS 2012 report shows Indonesia CPR value of 61.9 percent (8) but PMA 2020 reports in 2015 showed a decrease of 0.8 percent to 61.1 percent. Woman contraceptive improvement can not be fulfilled, or unmet need in 2015 was 14.51 percent. In general, the drop of use of Indonesian women who stop using contraception within 12 months after the installation is 27 percent (8).

Primary health centers are the closest place for women to obtain contraceptives. A good program and optimal access can influence contraceptive use in the community. Optimal access could be interpreted as providing the right services at the right time and the right place (9). Someone inclined to want health care on the same day as desired. When health facilities are unable to provide services on the same day, may be due to operating hours or other reasons, it causes a person's willingness to come back at another time (10). The length of waiting time can be associated with the internal system of health facilities, availability of skilled personnel, facilities, or opening hours. Because it has not many studies that review the duration of health services, so the researcher wanted to examine frequency of contraceptive service days and see the correlation with the utilization of family planning in Indonesia.

\section{MATERIALS AND METHODS}

The research method in this study is quantitative research with cross sectional study 
design used data Performance Monitoring and Accountability (PMA) 2020 in Indonesia in 2015. Project PMA 2020 is a survey which aims giving back to surveillance and evaluation system on a global scale by providing information in order reporting, planning, operational decision making and advocacy at the district or city, provincial, national, and global.

The research subject is all over the health community center in Indonesia who became the respondent of PMA 2020. Sampling method was performed stratified two-stage (two-stage stratified sampling). The variable in this study are frequency of family planning services, the proportion of modern contraceptive users, the women in reproductive age proportion of extremely and ordinary poor, women in reproductive age proportion of secondary education and above, the women in reproductive age proportion of 15-35 year old respondent, women in reproductive age proportion have health insurance, health centers providing> 5 methods of contraception, health centers stock out of $>5$ methods. This study was used a questionnaire instrument woman PMA 2020, a household questionnaire, and a questionnaire of health service point. The data analysis was conducted the univariable then present on tables and figures, bivariable use t-test and correlation with a significance level of $<0.05$ and also used a multivariable analysis. Figure 1 sampling flow chart

\section{RESULTS AND DISCUSSIONS}

The study involved health centers in Indonesia. A total of 210 districts had a health centers be included in the analysis. Each district selected one health center, which later merged with several districts in a nearby location to reach the subject of at least 30 people of served women in reproductive age. The final result obtained by a combined 104 district called the area of research and will be analyzed until the end.
Table 1. Subjects Characteristic

\begin{tabular}{|c|c|c|c|c|}
\hline Variable & Mean & Min & Max & SD \\
\hline $\begin{array}{l}\text { Proportion women in } \\
\text { reproductive age use } \\
\text { modern contraceptive }\end{array}$ & 61,6 & 16,1 & 88,6 & 14,3 \\
\hline $\begin{array}{l}\text { Proportion women in sosio- } \\
\text { economic low-very low }\end{array}$ & 34,6 & 0 & 96,2 & 22,2 \\
\hline $\begin{array}{l}\text { Proportion women in } \\
\text { education middle-high }\end{array}$ & 66,7 & 22,6 & 97,4 & 66,7 \\
\hline $\begin{array}{l}\text { Proportion women age } 15- \\
35 \text { yo }\end{array}$ & 56,8 & 26,7 & 80,3 & 10 \\
\hline $\begin{array}{l}\text { Proportion women have } \\
\text { health assurance }\end{array}$ & 52,2 & 10 & 93,5 & 14,9 \\
\hline
\end{tabular}

Every single variable had a normal distribution data. More than half of women in reproductive age are used modern contraceptive, however from this study found the gap of variation distribution in each district. It also found a considerable gap in the proportion of economy, which is their mean population of poor people is still very high. The condition was also seen in the average proportion of people who have health insurance is only half from population. The insurance ownership variation is disparities between regions. Two out of three people have a secondary and a higher education level. More than half the population aged between 15-35 years old.

Health facilities in this research are health centers in the district are then combined with some of the surrounding district. Table 4 illustrates that more than two-thirds of the region of research already have health centers are provide family planning services entirely over 5 days a week. In addition, most of the study area did not experience any stock outs. Health Center which provides more than 5 planning methods as much as two-thirds than total health centers were interviewed. Health Center respondents evenly spread in the Java-Bali and outside Java-Bali.

Frequency contraceptive day services statistically not significant with contraceptive utilization, but practices related with contraceptive utilization. When all health centers provide 
Table 2. Health Facilities Characteristics

\begin{tabular}{lr}
\hline \multicolumn{1}{c}{ Variable } & N (\%) \\
\hline $\begin{array}{l}\text { Frequency of contraceptive service days } \\
\text { All Puskesmas offer more than } 5 \text { days/ }\end{array}$ & $79(76)$ \\
weeks & $25(24)$ \\
$\begin{array}{l}\text { Not all Puskesmas offer more than } 5 \text { days/ } \\
\text { weeks }\end{array}$ & \\
$\begin{array}{l}\text { Stock out >5 methods } \\
\text { There is puskesmas which stock out }\end{array}$ & $7(6,7)$ \\
$\begin{array}{l}\text { All of the puskesmas aren't stock out } \\
\text { Offer more than } 5 \text { methods }\end{array}$ & $97(93,3)$ \\
$\begin{array}{l}\text { Not all Puskesmas offer more than } 5 \\
\text { methods }\end{array}$ & $35(33,6)$ \\
$\begin{array}{l}\text { All Puskesmas offer more than } 5 \text { methods } \\
\text { Region }\end{array}$ & $69(66,4)$ \\
$\begin{array}{l}\text { Outside Java and Bali } \\
\text { Java Bali }\end{array}$ & $54(51,9)$ \\
\end{tabular}

Table 3. Bivariable Analysis Correlation Health Service Operation Hours And Other Variables

\begin{tabular}{lcccc}
\hline \multicolumn{1}{c}{ Variable } & Coef. & $\mathbf{C l}$ & $\mathbf{P}$ & $\mathbf{r}^{2}$ \\
\hline $\begin{array}{l}\text { Frequency of } \\
\text { contraceptive } \\
\text { service days }\end{array}$ & 5,97 & $-0,46-12,4$ & 0,068 & \\
$\begin{array}{l}\text { Stock out }>5 \\
\text { methods }\end{array}$ & 9,51 & $-1,48-20,49$ & 0,089 & \\
$\begin{array}{l}\text { Offer }>5 \text { methods } \\
\text { Region }\end{array}$ & 5,14 & $-0,68-10,95$ & 0,083 & \\
$\begin{array}{l}\text { Proportion } \\
\text { women in sosio- }\end{array}$ & 6,20 & $0,75-11,65$ & 0,026 & \\
$\begin{array}{l}\text { economic low- } \\
\text { very low }\end{array}$ & $-0,04$ & $-0,16-0,09$ & 0,554 & $-0,06$ \\
$\begin{array}{l}\text { Proportion } \\
\text { woman in } \\
\text { education middle- } \\
\text { high }\end{array}$ & $-0,09$ & $-0,27-0,09$ & 0,310 & $-0,10$ \\
$\begin{array}{l}\text { Proportion } \\
\text { women age 15- }\end{array}$ & 0,33 & $0,05-0,60$ & 0,019 & 0,14 \\
$\begin{array}{l}\text { 35 yo } \\
\begin{array}{l}\text { Proportion } \\
\text { women have } \\
\text { health assurance }\end{array}\end{array}$ & $-0,19$ & $-0,38--0,01$ & 0,038 & $-0,20$ \\
\hline
\end{tabular}

Note: coef. $=$ regression coefficient, $\mathrm{Cl}=$ confidence Interval, $\mathrm{P}=$ significance, $\mathrm{r}^{2}=$ pearsoncorrelation determinant

contraceptive more than five days a week, will increase the proportion $6 \%$. Both variable stock out more than five methods and providing more than five methods do not have statistically relation but have in practice effect. When all health centers do not occur stock out more than five methods will increase $9 \%$ contraceptive utilization. When health center providing more than five methods will increase $5 \%$ contraceptive utilization.

Proportion of women aged under 35 years old statistically correlated with the proportion of contraceptive user and positively correlated. The more female aged under 35 years old in area, will increase contraceptive utilization. Health insurance ownership statistically significant with contraceptive utilization and negatively correlated. When the proportion of health insurance owner increases, it will reduce the proportion of modern contraceptive users.

This study has conducted an analysis of confounding. The analysis show that stock out was variable that can influence the proportion contraceptive user. The analysis involves a variable stock out makes frequency contraceptive days services statistically significant. Proportion health insurance ownership give effect to main determinant variable. After added the variable insurance ownership in analysis, there is decreased the main variable coefficient more than $10 \%$.

Variable were included in the multivariable analysis model is one that has significant value less than 0,25 in bivariate analysis and not included the confounding variable. Variable region, age, and the health insurance ownership were not included in model. The best model is the model with the smallest AIC score. Model 1 analysis the main independent variable with main dependent variable. There is no statistically relationship between main independent with dependent variable, but practically there is relationship. When all health centers provide family planning services more than five days, will increase the proportion of contraceptive users by 6 percent.

Models 2 and 3 are an analysis of the main variables by adding external variables one by one. Model 2 inserting the variable stock out, the result show that frequency contraceptive day services statistically significant with contraceptive 
Table 4. Multivariabel Analysis

\begin{tabular}{lccc}
\hline Variabel & Model 1 & Model 2 & Model 3 \\
\hline Frequency of contraceptive & 5,967 & $6,969^{*}$ & $6,896^{*}$ \\
service days & {$[-0.459,12.39]$} & {$[0.568,13.37]$} & {$[0.585,13.21]$} \\
Stock out $>5$ methods & & $11,30^{*}$ & $12,47^{*}$ \\
& & {$[0.385,22.22]$} & {$[1.641,23.29]$} \\
Offer $>5$ methods & & & $5,690^{*}$ \\
& & & {$[0.0136,11.37]$} \\
N & 104 & 104 & 104 \\
AIC & 847,8 & 845,5 & 843,5 \\
\hline
\end{tabular}

Note: $95 \%$ confidence intervals [], ${ }^{*} p<0.05,{ }^{* *} p<0.01,{ }^{* * *} p<0.001, A I C=$ Akaike's Information Criterion

user. Proportion contraceptive user increase $7 \%$ when all health center opens more than 5 days a weeks after considering the stock out. The best model is model 3 , the model with the lowest AIC score. In model 3 can be interpreted that the frequency contraceptive day services statistically correlated with utilization after considering variable stock out and how many methods provides. When all health facilities in the region provide family planning services more than five days a week, will increase the proportion of modern family planning users by 6.9 percent after considering the stock out of variables and methods are provided.

This study analyzed 104 regions by looking at first-level health service (PUSKESMAS) and women in reproductive age served in the area. In general, the aim of this study is to look at the relationship between the frequency of family planning services in a week by the health service and the utilization of modern family planning in women in reproductive age in the region. The results of this study illustrate that there is no statistical relationship between the frequency of family planning services and the use of family planning. But when seen in practice, found a positive relationship between the two variables.

When all health service in the region provide family planning services for more than 5 days a week, they are able to increase the proportion of family planning use by $6 \%$. This finding is in line with what happened in Cambodia (11), people are less able to utilize health services because they are often not available when needed. People tend to want to get the services they want right away. When a service provider is unable to be present at that time, consumers tend to be unwilling to return at another time (10).

The health service in this study were only the first level health facilities owned by the government, without considering the private sector. Health service in Indonesia are spread throughout the region. In each district has one hospital and several private hospitals. While at the smallest level, namely the village, the government has provided a PUSKESMAS which is very easy to reach by all levels of society. In addition, health workers serving in health facilities are given the opportunity to conduct private practice outside the working hours of health facilities (12). This situation illustrates that people in Indonesia are given many facilities to fulfill their rights to obtain health services.

One of the points to measure access was its utility. But not always increasing access in an area means good. When the availability of services was improved, this will increase the number of services in a region. The impact is that visits to each service will decrease from before. So that there will be no increase in utilization 
trends in these services. This study found that the region, in this case was Java-Bali region and outside Java-Bali region, influenced the use of modern family planning in women reproductive age. The proportion of women reproductive age who living in the Java-Bali region is $6 \%$ higher than women reproductive age outside the JavaBali. Indonesia is a country with many islands, it can affect the time needed for the distribution of family planning devices. In addition, the central government where located in Java, makes information spread faster in the Java region, so it was big opportunities for higher use of family planning.

Stock out is one of the factors that influence a person's use of contraception. In this study it was found that practically, the availability of contraceptive methods in PUSKESMAS was able to influence the use of contraception in women reproductive age. When in all health service in the region there was no stock out of the contraceptive method, it was able to increase the prevalence of contraceptive use by $9.5 \%$. The availability of methods is one of the determinants of satisfaction and continuity of contraceptive use in a person $(13,14)$. This stock out relates to a person's limitations in choosing what they want. When someone wants a modern family planning method, but health facilities are not able to serve because their supplies run out, it causes many people didn't want to choose other methods and discontinuity occurs.

The method provided by the health facility was not statistically related to the use of family planning, but in practice when all health facilities in the region are able to provide more than 5 methods an increase in the proportion of family planning users by $5 \%$ will occur. The more contraceptive methods offered by a health facility, the more contraceptive use rates will increase in the community. When associated with stock out, it is known that $65 \%$ of PUSKESMAS that provide more than the contraceptive method do not have a history of stock outs. It can see that the availability of methods in Indonesia is quite good.

Women's economic was not statistically related to the use of contraception. There was a negative correlation between these two factors, although the value was very small. It can be interpreted that more region with low economic women, the proportion of contraceptive use will be lower. Many low-income economic communities assume that children are valuable assets to improve their economy. Children are human resources that can be used to cultivate land, continue businesses, and work as workers without pay. That mindset can hamper the success of family planning programs (15).

Proportion of women with secondary or higher education was not related with contraceptive use. That two variables were negatively correlated. It can be interpreted that the region with a higher proportion of middle and high educated women, lower the use of contraception. The 2012 IDHS results provide a similar picture to the findings of this study. $39 \%$ of high school and tertiary education graduates use modern contraception. This finding was contrary to the statements of several sources(16-19) which states that education was related to contraceptive use. The higher person's education, the more chance they use contraception. Women in reproductive age with higher education tends to have more knowledge and broader views about a matter. The consideration for making decisions will be more rational.

This research found a negative relationship between education and the use of modern contraception. These findings can be interpreted that when an area increases in the proportion of highly educated population, the proportion of contraceptive use is actually low. As Nasution argues (19), someone with higher education tends to be more rational. But it could be with minimal information or a more dominant personal 
perception, causing them to agree more with the opinion that there will be no problem even if they do not use family planning. Because they believe that they can overcome various problems that will arise in the future(20).

The proportion of women aged $15-35$ is related to contraceptive use. An area with a high proportion of women aged 15-35 years tends to have a higher proportion of people using family planning. The findings in this study are in line with the 2012 IDHS which states that women under the age of 35 who use modern contraception are $59 \%$.

The proportion of health insurance ownership is negatively correlated with contraceptive use. In an area with a high proportion of insurance owners, the use of contraception is low. This can happen because someone who has health insurance, does not understand what services are financed by the insurance. When the actual contraception is covered by insurance, the public does not know that.

One of the objectives of the implementation of health insurance is to overcome obstacles related to one's ability to pay contraceptive costs, subsidies and health insurance programs are very helpful to increase contraceptive use in an area $(2,21)$. When a health insurance program is implemented in a country that covers the cost of contraception, there will be an increase in contraceptive users (22).

Confounding analysis was performed in this study. After conducting the analysis, it is known that the variable proportions of women that have health insurance, stock out more than 5 methods, and region are variables that are able to give a change in the significance value of more than $10 \%$. The stock out variable gives a change of $16 \%$ but the final result of the analysis causes a change in the significance of the main variable. When the main variables are analyzed without including other variables, the frequency of family planning services is not related to contraceptive use. However, when analyzed by including the stock out variable, the service frequency variable is related to the proportion of contraceptive use. With these considerations so that although the stock out variable has an effect, it is still included in multivariable analysis.

Multivariable analysis is used to determine the contribution of various different causes to an outcome. The results of multivariable analysis showed that model 3 was the best, with the lowest AIC value. When all health facilities in the region provide family planning services for more than 5 days a week, it will increase the proportion of modern family planning use by 6.9 percent after considering the stock out variable and the methods provided. When a health facility provides a full week of service, but the supply of contraceptives in the warehouse is limited and the methods offered to wus are few, it will not be able to increase the proportion of contraceptive use in the region.

\section{CONCLUSION AND RECOMMENDATION}

Three quarters of the puskesmas involved in this study provided family planning services more than 5 days a week. Almost all puskesmas have no contraception stock out. More than twothirds of puskesmas serve more than 5 modern methods of contraception, and the distribution of puskesmas throughout Indonesia is equally. Frequency of family planning service days is statistically related to contraceptive use in women after considering the stock out variable and the methods provided. The frequency of FP services and methods offered in health facilities has been good, it needs to be maintained and balanced with improved services for the community. The frequency of services, the supply of contraceptives, and the number of methods offered by health facilities are able to affect the proportion of modern contraceptive users. So that all health facilities both private and government-owned should be able to provide 
services more than 5 days a week, no methods are exhausted, and at least provide more than 5 methods of contraception.

\section{REFERENCES}

1. Mbizvo MT, Phillips SJ. Family planning: Choices and challenges for developing countries. Best Practice and Research: Clinical Obstetrics and Gynaecology. 2014;28(6):931-43.

2. Kavanaugh ML, Anderson RM, Levy M, Magar V, Sialondwe D, De Oliveira LH, et al. Contraception and beyond: The health benefits of services provided at family planning centers. Guttmacher Inst. 2013;31(Suppl 3):C99-108.

3. Skiles MP, Cunningham M, Inglis A, Wilkes B, Hatch B, Bock $A$, et al. The effect of access to contraceptive services on injectable use and demand for family planning in Malawi. International Perspectives on Sexual and Reproductive Health. 2015;41(1):20-30.

4. Powell V, Bulatao R, Palmore JA, Ward SE. Choosing a Contraceptive: Method Choice in Asia and the United States. Vol. 19, Contemporary Sociology. 1990. 414 p.

5. Aday LA, Andersen R. A framework for the study of access to medical care. Health Services Research. 1974;9(3):208-20.

6. BPS. Perkiraan Penduduk Beberapa Negara, 2000-2014 [Internet]. 2016. Available from: http://bps.go.id/linkTableDinamis/view/id/960.

7. Westoff CF, Ochoa LH. Comparative Studies 5: Unmet Need and the Demand for Family Planning [Internet]. Institute for Resource Development; Columbia. 1991. Available from: https://dhsprogram.com/pubs/pdf/CS5/CS5.pdf

8. Bps. Survei Demografi dan Kesehatan Indonesia. 2013;

9. Rogers A, Flowers J, Pencheon D. Improving access needs a whole systems approach. And will be important in averting crises in the millennium winter. Vol. 319, BMJ (Clinical research ed.). 1999. p. 866-7.

10. Murray M, Bodenheimer T, Rittenhouse D, Grumbach K. Improving Timely Access to Primary Care: Case Studies of the Advanced Access Model. Journal of the American Medical Association. 2003;289(8):1042-6.

11. Khun S, Manderson L. Health seeking and access to care for children with suspected dengue in Cambodia: An ethnographic study. BMC Public Health. 2007;7:1-10.

12. Heywood P, Harahap NP. Health facilities at the district level in Indonesia. Aust New Zealand Health Policy. 2009;6(1):1-11.

13. Hutchinson PL, Do M, Agha S. Measuring client satisfaction and the quality of family planning services: A comparative analysis of public and private health facilities in Tanzania, Kenya and Ghana. BMC Health Services Research. 2011;11(203).

14. Burke HM, Ambasa-Shisanya C. Qualitative study of reasons for discontinuation of injectable contraceptives among users and salient reference groups in Kenya. African Journal of Reproductive Health. 2011 Jun;15(2):67-78.

15. Price NL, Hawkins K. A conceptual framework for the social analysis of reproductive health. Journal of Health, Population and Nutrition. 2007;25(1):24-36.

16. Melka AS, Tekelab T, Wirtu D. Determinants of long acting and permanent contraceptive methods utilization among married women of reproductive age groups in western Ethiopia: A cross-sectional study. Pan African Medical Journal. 2015;21:1-10.

17. Asiimwe JB, Ndugga P, Mushomi J, Manyenye Ntozi JP. Factors associated with modern contraceptive use among young and older women in Uganda; A comparative analysis. BMC Public Health. 2014;14(1):1-11.

18. Stephenson R, Baschieri A, Clements $S$, Hennink M, Madise N. Contextual influences 
on modern contraceptive use in sub-Saharan Africa. American Journal of Public Health. 2007;97(7):1233-40.

19. Nasution SL, Wahyuni S. Faktor-Faktor yang Mempengaruhi Penggunaan MKJP di Enam Wilayah Indonesia. Jakarta; 2011.

20. Chipeta EK, Chimwaza W, Kalilani-Phiri L. Contraceptive knowledge, beliefs and attitudes in rural malawi: Misinformation, Misbeliefs and Misperceptions. Malawi Medical Journal. 2010;22(2):38-41.
21. Bearak JM, Finer LB, Jerman J, Kavanaugh ML. Changes in out-of-pocket costs for hormonal IUDs after implementation of the Affordable Care Act: An analysis of insurance benefit inquiries. Contraception [Internet]. 2016;93(2):139-44. Available from: http://dx.doi.org/10.1016/j. contraception.2015.08.018

22. DillsAK, GrecuAM. Effects of state contraceptive insurance mandates. Economics and Human Biology. 2017;24:30-42. 